УДК 349.2

DOI https://doi.org/10.32844/2618-1258.2019.5-2.15

ОБУШЕНКО Н.М.

\title{
МЕТА, ЗАВДАННЯ ТА ФУНКЦІї КОДИФІКАЦІї ЯК СПОСОБУ СИСТЕМАТИЗАЦІЇ ТРУДОВОГО ЗАКОНОДАВСТВА
}

Метою статті є визначення мети, завдань та функцій кодифікації як способу систематизації трудового законодавства. Так, у статті на основі аналізу наукових поглядів учених та норм чинного законодавства України визначено та охарактеризовано мету, завдання та функції кодифікації як способу систематизації трудового законодавства. Доведено, що у сучасних умовах кодифікація трудового законодавства є об'єктивною необхідністю та водночас своєрідною відповіддю на ту правову невизначеність, яка сьогодні існує у сфері регулювання трудових правовідносин. 3'ясовано, що у сучасних умовах кодифікація трудового законодавства є об'єктивною необхідністю та водночас своєрідною відповіддю на ту правову невизначеність, яка сьогодні існує у сфері регулювання трудових правовідносин. Кодифікація як спосіб систематизації трудового законодавства дає можливість, по-перше, вдосконалити трудове законодавство, що підвищить ефективність регулювання трудових і пов'язаних із ними правових відносин, адже замість чисельних нормативних актів приймається один, більш досконалий, норми якого покликані більш якісно покращити захист та забезпечення реалізації трудових прав працівників; по-друге, зробити трудове законодавство більш доступним та зрозумілим для пересічного громадянина, що якісно підвищує рівень правової свідомості у суспільстві; по-третє, вирішити низку завдань соціального, економічного та політичного характеру. Зроблено висновок про те, що здійснення кодифікації трудового законодавства України не $є$ панацеєю та не вирішить абсолютно всіх нагальних проблем у цій сфері. Для того щоби кодифікація принесла бажаний результат, необхідно адаптувати положення інших нормативно-правових актів відповідно до змін, які були внесені до Кодексу. Крім того, необхідно створити всі необхідні матеріальні та технічні умови для того, щоби законодавчі новели запрацювали на практиці. Важливим аспектом є проведення ретельної перевірки соціально-економічної та політичної ситуації в країні, а також аналізу наявних актів щодо визначення неточностей та колізій у них.

Ключові слова: трудове законодавство, мета, завдання, функиії, систематизачія, нормативно-правовий акт, кодифікаиія.

The purpose of the article is to identify the purpose, objectives and functions of codification as a way of systematizing labor law. Thus, in the article, on the basis of the analysis of scientific views of scientists and norms of the current legislation of Ukraine, the purpose, tasks and functions of codification are defined and characterized as a way of systematizing labor legislation. It is proved that in the present conditions codification of labor law is an objective necessity and at the same time a peculiar answers to the legal uncertainty that exists today in the sphere of regulation of labor relations. It has been found out that in the present conditions codification of labor law is an objective necessity and at the same time a peculiar answers to the legal uncertainty that exists today in the sphere of regulation of labor relations. Codification, as a way to systematize labor law, makes it possible: first, to improve labor law, thereby improving the efficiency of regulation of labor and related legal relations, because instead of numerous regulations, one more sophisticated norm is adopted, whose norms are intended to improve protection more qualitatively and ensuring the realization of workers' labor rights; second, it makes labor law

(C) ОБУШЕНКО Н.М. - кандидат юридичних наук, старший науковий співробітник секретаріату Вченої ради (Дніпропетровський державний університет внутрішніх справ) 
more accessible and understandable to the average citizen, which qualitatively increases the level of legal consciousness in society; third, to address a range of social, economic and political challenges. It is concluded that the implementation of the codification of the labor legislation of Ukraine is not a panacea and will not solve absolutely all urgent problems in this area. In order for the codification to produce the desired result, it is necessary to adapt the provisions of other legal acts in accordance with the amendments made to the Code. In addition, it is necessary to create all the necessary material and technical conditions in order for the legislative novelties to work in practice. An important aspect is a thorough review of the socio-economic and political situation in the country, as well as an analysis of existing acts to determine inaccuracies and conflicts in them.

Key words: labor legislation, purpose, tasks, functions, systematization, normativelegal act, codification.

Вступ. Сьогодні ні в кого не викликає сумніву необхідність здійснення такого виду систематизації трудового законодавства України, як кодифікація. Про це неодноразово зазначала чимала кількість учених. Так, О.М. Ярошенко ще на початку двохтисячних років наголошував на тому, що прийняття в Україні Трудового кодексу дасть змогу впорядкувати трудові відносини, підвищити їх гнучкість, звільнити роботодавця від економічно невиправданих витрат на забезпечення гарантій і компенсацій працівникам. Цим шляхом скоротяться можливості для розвитку нелегальних трудових відносин, відбудеться реальне підвищення (порівняно $з$ наявною ситуацією) рівня захисту прав і законних інтересів працівників. Вчений акцентує увагу на тому, що новий Трудовий кодекс має не стільки проголошувати й фіксувати рівні та нормативи охорони праці, пільги та компенсації, скільки стимулювати розвиток економіки, що створить умови для реального забезпечення зазначених норм. Головними умовами цього $є$ прискорене впровадження досягнень науково-технічного прогресу, систематичне поновлення технічної бази, а це, як показує досвід передових в економічному плані країн, передбачає широку участь в управлінні виробництвом безпосередніх виробників матеріальних благ - працівників через їх представницькі органи $[1$, с. 44]. О.А. Любчик у своєму науковому дослідженні також зазначала, що множинність нормативно-правових актів, їх неузгодженість, фрагментарність, невідповідність потребам сучасного розвитку суспільних відносин, що утворюються, змінюються чи припиняються у сфері трудового права, недостатність правових інструментів для реалізації норм права на практиці, їх технічна недосконалість, відсутність чіткої логіки побудови структури нормативно-правових актів, а також хаотичність дії такого законодавства обумовлюють причини проведення кодифікаційної діяльності в системі трудового права України [2, с. 103].

Справедливо відзначити, що на важливість кодифікації трудового законодавство неодноразово звертав увагу сам законодавець. Зокрема, у своїй доповіді представник Міністерства соціальної політики пояснює, що необхідність осучаснення трудового законодавства зумовлена докорінними змінами всієї системи суспільних відносин, що відбуваються в Україні у зв'язку 3 формуванням ринкових відносин та соціально-економічними перетвореннями, а також тією чи іншою мірою пов'язані з працею. Крім того, сучасна система принципів трудового права не цілком відповідає потребам часу, меті та завданням незалежної України. У зв'язку з цим вона має бути переглянута з урахуванням змін у суспільному розвитку нашої держави, а також 3 урахуванням економічних реалій. Нові ризики та виклики (насамперед, кризові явища в економіці) вимагають запровадження нестандартних підходів до реалізації трудових прав та трудових відносин [3]. Яскравим підтвердженням намагань законодавства кодифікувати трудове законодавства $є$ також те, що в Україні вже досить великий період часу на розгляді залишається проєкт Трудового кодексу, який, до речі, є далеко недосконалим і також потребує перегляду. Отже, не викликає сумніву, що сьогодні подальший розвиток трудо-правових відносин та їх якісне й ефективне регулювання потребують реформування трудового законодавства України з обов'язковою його кодифікацією.

Проблема систематизації трудового законодавства неодноразово перебувала в полі зору вчених із галузі трудового права. Зокрема, їй приділяли увагу Н.П. Долгіх, В.П. Марущак, А.Ю. Бабаскін, Ю.В. Баранюк, С.В. Дріжчана, О.А. Любчик, В.О. Антоненко, О.В. Петришин, С.П. Погребняк, В.С. Смородинський, Л.П. Гаращенко. Однак наукові праці окреслених учених мали комплексний характер, а різні способи систематизації трудового законодавства розглядались лише поверхнево. 
Постановка завдання. Метою статті є визначення мети, завдань та функцій кодифікації як способу систематизації трудового законодавства.

Результати дослідження. Аналіз наукових джерел дає змогу відзначити, що незалежно від того, в якій галузі права здійснюється кодифікація законодавства, вона $є$ не просто діяльністю уповноважених суб'єктів із систематизації нормативно-правових актів, які містять норми, що спрямовані на врегулювання однорідних правовідносин, але й комплексним його вдосконаленням. В цьому контексті відзначимо, що кодифікація передбачає можливість створення нових, більш досконалих норм, а також скасування застарілих положень, що дасть змогу уникнути дублювання норм права, виникнення колізій тощо. Переходячи безпосередньо до розгляду проблеми кодифікації трудового законодавства, маємо відзначити, що їй приділялось чимало уваги збоку фахівців трудового права.

Так, наприклад, О.А. Любчик, досліджуючи низку підходів до розуміння сутності кодифікації, дійшла висновку, що кодифікація трудового законодавства характеризується таким чином: це діяльність компетентних державних органів, тобто державна діяльність, результат якої має бути належним чином санкціонований і введений у дію за допомогою правових інструментів, які узгоджуються в єдиному механізмі запровадження цього результату в життя, тобто мати офіційний характер; кінцевим результатом такої діяльності $є$ новоутворений кодифікований акт, який буде містити правові норми, що були належними способами та методами системно оброблені, при цьому чинні норми, що $є$ дієвими та ефективними, впорядковуються та вносяться до цього акта, а застарілі норми скасовуються й замінюються новими, тобто відбувається впорядкування змісту та форми законодавства; зведений кодифікований акт може мати зовнішню форму у вигляді кодексу, положення, статуту; кодифікований акт повинен мати більш високу юридичну силу порівняно з іншими нормативно-правовими актами, що регулюють суспільні відносини в цій сфері, а нормативно-правові акти, що будуть утворюватися в майбутньому, мають відповідати основному кодифікованому акту задля уникнення колізій та прогалин [4, с. 53].

Для того щоби більш змістовно визначити сутність та призначення кодифікації трудового законодавства, необхідно визначитись із метою, завданнями та функціями систематизації. Мета, як вважає Г. Шикофф, є репрезентованою і бажаною майбутнім подією або станом, здійснення яких $є$ проміжним причинним членом на шляху до чогось; вона $є$ антиципованим поданням (передбаченням) результату нашої дії. 3 нею погоджуються засоби, необхідні для ії досягнення [5, с. 497]. О.М. Бандурка вважає, що мета - це бажаний стан об'єкта впливу чи кінцевий бажаний результат процесу управління, тому саме від реальності, законності та правильності iii визначення залежить бажаний результат [6, с. 16]. Таким чином, мета кодифікації трудового законодавства - це той бажаний кінцевий результат, якого бажають досягти суб'єкти кодифікації в процесі здійснення такої діяльності. Аналіз наукової літератури дає змогу говорити про те, що мета кодифікації має багатоаспектний характер.

Так, О.Я. Рогач зазначає, що правовою метою кодифікації є впорядкування нормативної основи права, забезпечення найбільш доцільного процесу реалізації права, поліпшення структури кодифікаційних актів, удосконалення їх логіки, мови, стилю. Кодифікація завжди має офіційний характер і здійснюється виключно державними органами. Кодифікаційна діяльність здійснюється періодично, тобто залежно від нагромадження нормативного матеріалу та об'єктивної необхідності його всебічного опрацювання. Кодифікація вимагає, щоби в проєкт нового нормативно-правового акта, який має прийматися, включались лише ті норми, що зберегли свою дію та виправдовують себе, а також щоби вводились нові норми, вносилися зміни й доповнення, усувались прогалини у правовому регулюванні. Проєкт кодифікованого акта подається до компетентного органу у звичайному порядку, але одночасно мають подаватися пропозиції, спрямовані на відміну акту (актів) або їх частини, що фактично втратили силу у зв'язку з прийняттям нового нормативно-правового акта, а також якщо вони містять положення, що увійшли до нового нормативно-правового акта [7, с. 10].

Більш вдалою є позиція Л.П. Гаращенка, який у своєму науковому дослідженні відзначив, що головні цілі кодифікації трудового законодавства можна поділити на юридично-технічні, соціальні та політичні. Сутність юридично-технічних цілей полягає в раціоналізації та уніфікації трудового законодавства України, визначенні чіткої структури кодифікованого акта, чіткості та однозначності формулювань. Головними ознаками соціальної мети в кодифікації трудового законодавства $є$ збереження й подальший розвиток правових норм, спрямованих на узгодження прав та інтересів працівника й роботодавця, всіх учасників трудових відносин. Оновлення та модернізація трудового законодавства на основі світового та міжнародного дос- 
віду, врахування особливостей та здобутків національного трудового права є сутністю політичної мети кодифікації [8, с. 122]. 3 вищезазначеним науковцем складно не погодитись, однак, на нашу думку, Л.П. Гаращенко занадто розмито підходить до визначення мети такої діяльності, охоплюючи при цьому завдання кодифікації.

Отже, на нашу думку, мету кодифікації трудового законодавства можна поділити на дві складові частини, а саме основну та факультативну, яка випливає з основної. Ключовою метою, на наше переконання, є систематизація, впорядкування та подальше вдосконалення законодавства про працю. Водночас додатковою метою, яку переслідує кодифікація трудового законодавства, $є$ забезпечення більш ефективного та якісного регулювання та впорядкування трудових i пов'язаних з ними правовідносин у нашій країні. Відомо, що досягненню мети має передувати вирішення конкретних завдань, які є своєрідними мікроцілями.

О.А. Любчик, досліджуючи суб'єкти кодифікації трудового законодавства, відзначає, що в процесі здійснення кодифікації вони мають виконати такі завдання, як розроблення концепції здійснення кодифікації трудового законодавства; опрацювання всіх нормативно-правових актів, які врегульовують трудові правовідносини; виділення норм, якіє застарілими та існування яких не відповідає стану розвитку трудових відносин у державі; виключення норм, які не можуть врегульовувати трудові відносини на належному рівні; проведення перевірки розробленого кодифікованого нормативно-правового акта трудового законодавства щодо відповідності його міжнародним стандартам (за невідповідності слід дослідити відповідні міжнародні норми, які врегульовують трудові відносини, а також включити їх до кодифікованого нормативно-правового акта); стабілізація чинного трудового законодавства; ліквідація колізій, які існують у трудовому законодавстві; комплексне врегулювання трудових відносин; виключення норм, які дублюються в різних нормативно-правових актах; зведення до мінімуму прогалин у правовому регулюванні трудових відносин [9, с. 107].

3 вищезазначеною думкою слід погодитись, однак ми вважаємо, що вона не відображає всього переліку найбільш характерних завдань кодифікації. Саме тому ми, окрім зазначеного вище, на основі аналізу наукових поглядів вчених та норм чинного законодавства України можемо виділити такі завдання кодифікації трудового законодавства, як забезпечення системного викладу трудового законодавства, зміна його системи та перегляд орієнтирів; перетворення законодавства на більш зрозуміле та доступне для працівників і роботодавців; створення гармонії у відносинах між працівником та роботодавцем; адаптація норм трудового законодавства до соціально-економічних та політичних вимог сьогодення, а також до вимог, що висуваються до України європейською та світовою спільнотою в контексті євроінтеграції та глобалізації; забезпечення належного рівня захисту трудових прав працівників.

Завдання тісно пов'язані з такою категорією, як функції. Загалом функції - це напрями діяльності законодавства у сфері кодифікації. Саме вони, на нашу думку, найбільш змістовно то якісно відображають практичне призначення кодифікації трудового законодавства. До функцій кодифікації трудового законодавства України слід віднести:

стабілізуючу функцію (стабілізуюча функція кодифікації, як зазначає С.С. Алєксєєв, припускає, що законодавець на основі врахування об'єктивних тенденцій розвитку суспільних відносин створює такі нормативні приписи, які розраховані на тривалий термін їхньої дії; закріплення їх у кодифікованому акті надає самому акту більшої стабільності [10, с. 208]; ми переконані в тому, що стабілізуюча функція кодифікації трудового законодавства передбачає створення стабільного, постійного законодавства у сфері праці; забезпечення якісного розвитку трудових правовідносин, що, зокрема, передбачає налагодження взаємовідносин між працівником та роботодавцем);

правотворчу функцію (загалом правотворчість - це діяльність спеціально уповноважених державних органів і посадових осіб, що полягає у створенні (санкціонуванні) правових норм, які відображають наявні тенденції розвитку особи, суспільства й держави, діяльність, що $\epsilon$ знаходженням компромісу, який виникає в результаті врахування загального й приватного на користь усіх соціальних об'єктів; діяльність, спрямована на формування суспільної, групової та індивідуальної правосвідомості задля впорядкування й регламентації суспільних відносин, що об'єктивно мають правову природу [11]; правотворча функція кодифікації трудового законодавства передбачає, що в процесі такої діяльності законодавець на просто об'єднує однорідні норми в один нормативно-правовий акт, адже в процесі кодифікації можуть створюватись нові, більш досконалі норми);

фундаментальну функцію (фундаментальна функція кодифікації виражається в тому, що вона виробляє як загальногалузеві, так і внутрішньогалузеві нормативні основи; в ході коди- 
фікації зазвичай формуються норми, котрі регулюють найбільш важливі, принципові питання суспільного життя, визначаючи нормативні основи тієї чи іншої галузі (інституту) законодавства) [12, c. 209];

оновлюючу функцію (зміст цієї функції полягає в тому, що за допомогою кодифікації оновлюється зміст трудового законодавства, зокрема приймаються нові норми; вдосконалюється структура законодавства, робиться більш простою та зрозумілою);

узгоджувальну функцію (зміст окресленої функції проявляється в тому, щоб узгодити та поєднати норми різних нормативно-правових актів в рамках одного єдиного акта; ці норми мають доповнювати одна одну та в жодному разі не можуть суперечити положенням конституції та інших законодавчих актів).

Висновки. Таким чином, завершуючи представлене наукове дослідження, маємо відзначити, що у сучасних умовах кодифікація трудового законодавства є об'єктивною необхідністю та водночас своєрідною відповіддю на ту правову невизначеність, яка сьогодні існує у сфері регулювання трудових правовідносин. На нашу думку, кодифікація як спосіб систематизації трудового законодавства дає можливість, по-перше, вдосконалити трудове законодавство, що підвищить ефективність регулювання трудових і пов'язаних з ними правових відносин, адже замість чисельних нормативних актів приймається один, більш досконалий, норми якого покликані більш якісно покращити захист та забезпечити реалізацію трудових прав працівників; по-друге, зробити трудове законодавство більш доступним та зрозумілим для пересічного громадянина, що якісно підвищує рівень правової свідомості у суспільстві; по-третє, вирішити низку завдань соціального, економічного та політичного характеру.

На завершення хотілося б також звернути увагу на те, що здійснення кодифікації трудового законодавства України не є панацеєю та не вирішить абсолютно всіх нагальних проблем у цій сфері. Для того щоби кодифікація принесла бажаний результат, необхідно адаптувати положення інших нормативно-правових актів відповідно до змін, які були внесені до Кодексу. Крім того, необхідно створити всі необхідні матеріальні та технічні умови для того, щоби законодавчі новели запрацювали на практиці. Важливим аспектом є проведення ретельної перевірки соціально-економічної та політичної ситуації в країні, а також аналізу наявних актів щодо визначення неточностей та колізій у них.

\section{Список використаних джерел:}

1. Ярошенко О.М. Про необхідність кодифікації трудового законодавства України. Вісник Академії правових наук України. 2004. № 1 (36). С. 38-44.

2. Любчик О.А. Значення кодифікаційної діяльності в системах трудового права. URL: http://www.lj.kherson.ua/2014/pravo02/part_2/23.pdf.

3. Як Мінсоцполітики планує осучаснитй трудове законодавство? URL: https://news.dtkt.ua/ state/laws-and-regulations/55232.

4. Любчик О.А. Місце і роль кодифікації трудового законодавства. Науковий вісник Міжнародного гуманітарного університету. Серія: Юриспруденція. 2017. Вип. 29 (2). С. 52-54.

5. Философский словарь: основан Г. Шмидтом. 22-е новое, переработ. изд. под ред. Г. Шишкоффа / пер. с нем. ; общ. ред. В.А. Малинина. Москва : Республика, 2003. 575 с.

6. Бандурка O.M. Управління в органах внутрішніх справ України : підручник. Харків : Університет внутрішніх справ, 1998. 480 с.

7. Рогач О.Я. Кодифікаційні акти в системі законодавства України : автореф. дис. ... канд. юрид. наук : спец. 12.00.01 ; Київський національний університет ім. Тараса Шевченка. Київ, 2003. $19 \mathrm{c}$.

8. Гаращенко Л.П. Кодифікація трудового законодавства України: цілі та принципи. Юридична наука. 2011. № 1. С. 119-123.

9. Любчик О.А. Завдання суб'єктів кодифікації трудового законодавства. URL: http://www.nvppp.in.ua/vip/2016/2/tom_4/25.pdf.

10. Алексеев С.С. Государство и право: начальный курс. Москва : Юридическая литература, 1993. $176 \mathrm{c}$. 1994. $240 \mathrm{c}$.

11. Дмитриевцев К.Н. Процесс правотворчества в Российской Федерации. Москва,

12. Общая теория государства и права. Москва : Зерцало, 1998. 